\title{
MICROWAVE-ASSISTED EXTRACTION OF INULIN FROM JERUSALEM ARTICHOKE AND PARTIAL ACID HYDROLYSES
}
A. M. D. Alabadi
S. ch. Abood
Researcher
Prof.
Dept. Food Science -Coll. Agric., University of Baghdad
abaasmoarab@yahoo.com
Sabriabood1954@gmail.com

\section{ABSTRACT}

The Recent study aimed to identify the optimum conditions for inulin extraction from jerusalem artichoke tuber (JAT) powder using microwave assisted extraction method, and partially hydrolysis of purified inulin for producing fructooligosaccharide (FOS) using citric acid \& microwave energy. The extraction conducted at different temperature $(90-95) C^{\circ}$ at $(700 \mathrm{~W} / 5 \mathrm{~min}, 450 \mathrm{w} / 8 \mathrm{~min}$ and $350 \mathrm{w} / 14$ min). The extracted inulin was concentrated to $(50$ - 60) \% of original volume using rotary evaporator, and purified by lime method. The purified inulin extract was concentrated to 32 brix and mixed with acetone (3:1 acetone : extract), kept for $24 \mathrm{~h}$ at $4 \mathrm{C}^{\circ}$, then centrifuged at $10000 \mathrm{~g} / 15 \mathrm{~min}$., the precipitate dried at $55^{\circ} \mathrm{C}$. Acid hydrolysis of purified inulin carried out at different $\mathrm{pH}$ values (1.5, $2.5 \& 3.0)$ at $(90 \pm 2){ }^{\circ} \mathrm{C}$. Aliquot of inulin hydrolysate were taken after $(5,10,15,20,25 \& 30) \mathrm{min}$. and subjected to qualitative analysis by RP-HPLC and TLC. The obtained results indicated that the microwave assisted extraction at $700 \mathrm{~W} / 5 \mathrm{~min} . / 95^{\circ} \mathrm{C}$ was superior as compared to the rest. The yield of extracted inulin was about $39.61 \%$ and the extraction efficiency was $94.31 \%$, while the optimum condition for inulin acid hydrolysis appeared to be at $90{ }^{\circ} \mathrm{C} / 15 \mathrm{~min}$ at $\mathrm{pH} 2.5$ and $450 \mathrm{~W}$. The qualitative analysis using (RP-HPLC \& TLC) showed that the DP of inulin units ranged from ( 2 - 35) and for FOS ranged from $\quad(2-9)$ unit.

Keywords: hydrolysate, fructooligosaccharides, RP-HPLC, TLC, citric acid, microwave energy.

*Part of Ph.D. Dissertation of the $\mathbf{1}^{\text {st }}$ author.

العبادي وعبود 410-401:1(1)51:2020- مجلة العلوم الزراعية العراقية استخلاص الانيولين من مسحوق درنات الالمازة باستخدام طاقة المايكرويف وإنتاج سكريات الفركتوز القصيرة بالتحلل الجزئي الحامضي للانيولين

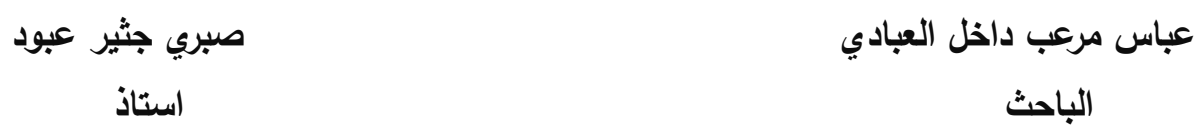

$$
\text { قسم علوم الأغذية -كلية الزراعة - جامعة بغداد }
$$

المستخلص

هدفت الدراسة الحالية الى تحديد الظروف المثلى لاستخلاص وتنقية الانيولين من مسحوق درنات الالمازة المحلية باستعمال المايكرويف عند مستويات طاقة بلغت (700 واط/ 5 دقيقة, 450 واط/ 8 دقيقة, 350 واط/ 14 دقيقة) بدرجة حرارة استخلاص تراوحت (90 - 95) مُ ونسبة خلط (1 : 30) (وزن/حجم), وكذلك تحديد الظروف المثلى لعملية التحلل الحامضسي الجزئسي عند درجات مختلفة مـن الاس

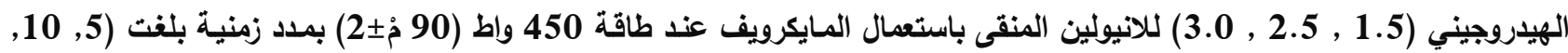
15, 20, 25 و 30) دقيقة, وتم التثخيص النوعي للانيولين المستخلص ونواتج التحلل بأستخدام تقنية

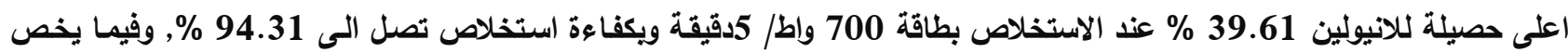
الظروف المثلى لتحلل الانيولين تفوقت المعاملة التي كان لها اس هيدرويني 2.5 ووقت تحلل 15 دقيقة في النسبة المئويـة لسكريات

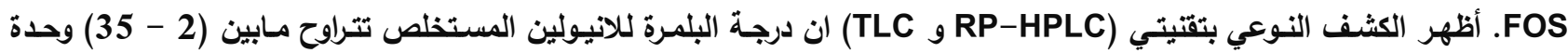

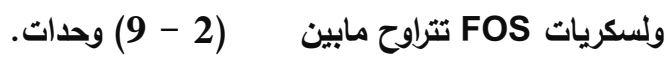
الكلمات الافتتاحية: متحلات, سكريات الفركتوز القصيرة, TLC , RP-HPLC, حامض الستريك, طاقة المايكرويف.

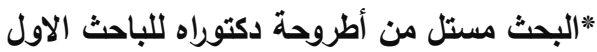




\section{INTRODUCTION}

Inulin is a linear polymer (polydisperse) of fructose linked by $\beta(2 \rightarrow 1)$ glycosidic bond and terminated with a D-glucose molecule linked to fructose by an $\alpha(1 \rightarrow 2)$ glycosidic linkage, as in sucrose (22). Inulin serves as storage carbohydrate in many members of the Asteraceae family such as Helianthus tuberosus (Jerusalem artichoke), Cichorium intybus (chicory), Tarax-acum officinalis (dandelion) and Inula helenium (elecampane) (10). Although today, chicory roots is the main crop used for industrial production of inulin, the pursuit of improving the extraction quality of other crops does not bring to a stop since. Jerusalem artichoke tubers (JAT) is containing about 14 to $19 \%$ of inulin (from fresh weight) so it can be a valuable source of inulin (2). Inulin extracted from natural sources is characterized by a degree of polymerization (DP) ranging (2 - 60) units. The oligosaccharides of inulin with DP less than 10 units called of fructo-oligosaccharide (FOS) is one of the bestknown prebiotics (25). Inulin and FOS are considered as functional food that is beneficial to human health through decrease the risk of some diseases like colon cancer, intestinal infections, diabetes, constipation, obesity and increase intestinal absorption of some minerals such calcium and magnesium in small intestine $(17,30)$. Several methods for inulin extraction from fresh JAT have been adopted $(13,28)$. These methods are time consuming with low extraction efficiency. Therefore it is necessary to develop methods for inulin extraction which improve the extraction efficiency (19). Microwave assisted extraction [MAE] is a process of using microwave power to heat the solution through the extraction of the sample in order to separate analytes from the sample matrix into the solvent, it is promising alternative method to extracted bioactive compounds from plant sources (43).The highly localized pressure and temperature can accelerate the migration of target compounds from the sample to the extraction solution, thus increases the extraction efficiency compared to conventional extracts. The extraction efficiency by microwave increased because it's volumetric heating effect, leading a higher temperature of solvent result due to dipole rotation of the solvent in the microwave field. Thus increasing the solubility of biocompounds (42). This study was aimed to optimize the conditions for inulin extraction from JAT powder and for partially hydrolysis of purified inulin for producing fructo-oligosaccharides (FOS) using citric acid and microwave power.

\section{MATERIALS AND METHODS}

\section{Chemicals and reagents}

All chemicals and reagents were of analytical reagent grade. These included potassium iodide, sodium hydroxide, Sodium acetate, tricalcium phosphate, sodium periodate, dinitrosalicylic acid, resorcinol and ascorbic acid (Merck, Germany). Citric acid, concentrated hydrochloric acid, maltodextrin and concentrated sulfuric acid (BDH England), Glucose, Fructose, Sucrose, Lactose, cellobiose, raffinose and 1-kestose were obtained from (Sigma-Aldrich, St. Louis, MO, USA) and (Merck Germany), Standard chicory inulin (Sigma, Berlin, Germany). Ethanol, butanol, aniline, diphenylamine, acetone, phosp-horic acid and glacial acetic acid were obtained from (Alpha ChemicalsIndia). Chromatographic silica gel $60 \quad(20$ $\mathrm{cm} \times 20 \mathrm{~cm}$ ) precoated glass plates were obtained from (Merck, Germany).

Determination of free fructose, total fructose \& inulin content in JAT

Free fructose, total fructose \& Inulin content were determined according to the method described by Saengkanuk et al. (33) using following formula:

$\mathrm{I}=k\left(\mathrm{~F}_{\text {tot }}-\mathrm{F}_{\mathrm{f}}\right)$

Where (I) is the inulin content, ( $\mathrm{F}_{\text {tot }}$ is total fructose content, $\left(\mathrm{F}_{\mathrm{f}}\right)$ is free fructose, and $(k)$ is a correction factor for the glucose part of the inulin and for the water loss during hydrolysis. In this study, $\mathrm{k}=0.995$ is adopted, this value is recommended for the unknown DP inulin.

\section{Preparation of JAT powder}

The JAT purchased from local market, washed with tap water to remove dust and other undesirable materials. The cleaned JAT was peeled and cut into slices $2 \mathrm{~mm}$ thick pieces. In order to avoid enzymatic browning, the slices were immersed in acidified boiled water $(0.1 \% \mathrm{w} / \mathrm{w}$ ascorbic acid) and left for $(2-3$ min.) to obtain white inulin powder, then the JAT slices were dried at $60{ }^{\circ} \mathrm{C}$ for $10 \mathrm{~h}$ in an oven, milled and sieved through an (50 mesh) 
sieve. The powdered JAT was kept in dry place, until extraction time (36).

Microwave-assisted extraction of Inulin

Inulin was extracted from JAT powder using a Microwave (silvercrest - German) at a frequency of $50 \mathrm{~Hz}$ s with six power settings according to Ruo-ling (32) method, with some minor modifications. Extraction of Inulin from JAT powder carried out as follows:

(a). Microwave power $700 \mathrm{~W}$, solid to liquid ratio $(1: 30)(\mathrm{w} / \mathrm{v})$ and extraction time $5 \mathrm{~min}$

(b). Microwave power $450 \mathrm{~W}$, same mixing ratio and extraction time $8 \mathrm{~min}$

(c). Microwave power $350 \mathrm{~W}$, same mixing ratio and extraction time $14 \mathrm{~min}$

The extraction process was conducted in duplicate. The obtained extracts were filtered through Muslin cloth and filter paper (Whitman No. 1), the residue of JAT was reextracted under the same conditions, then all filtrate were concentrated to $50-60 \%$ of the original volume using rotary evaporator. The extract was turbid due to the presence of protein, pectin, and cell wall materials. These impurities were removed according to method described by Paseephol et al. (28). The Inulin extract was concentrated to $32^{\circ} \mathrm{B}$ and precipitated according to $\mathrm{Ku}$ et al. (20) method. Acetone was used at ratios of $(3: 1$ $\mathrm{v} / \mathrm{v}$ ), then kept for $24 \mathrm{~h}$ in a refrigerator at $4^{\circ} \mathrm{C}$, centrifuged at $10000 \mathrm{~g}$ for $15 \mathrm{~min}$, the precipitated inulin was taken and dried in an oven at a temperature of $55^{\circ} \mathrm{C}$.

\section{Determination of inulin yield}

Inulin yield (\%) was calculated according to the following eq.

$\mathrm{Y}=(\mathrm{mI} / \mathrm{mJAT}) \times 100$

(Temkov et al.

38)

Where, $\mathrm{mI}$ is the inulin mass obtained from the extraction and mJAT is the mass of artichoke tubers taken for the extraction.

\section{Extraction and determination of pectin}

Pectin was extracted from JAT powder following the method described by Liu et al. (21), and the yield of pectin was calculated using the following formula equation:

Pectin yield $(\%)=(m 1 / m 2) \times 100$

Where $(m 1)(\mathrm{g})$ is the weight of dried pectin, $(m 2)(\mathrm{g})$ is the weight of dried material

Inulin hydrolysis for producing FOS: Partial hydrolysis of purified Inulin carried out due to method described by Fontana et al. (12).
Purified inulin solution (5\%) was used to prepare the working solution with different $\mathrm{pH}$ values being (1.5, 2.5 and 3.0); citric acid solution $10 \%$ was used to adjust the $\mathrm{pH}$ of the above solutions. All solutions were heated to $(90 \pm 2){ }^{\circ} \mathrm{C}$ using microwave power $450 \mathrm{~W}$ for time periods $(5,10,15,20,25 \& 30) \mathrm{min}$. After the partial hydrolysis of inulin, the $\mathrm{pH}$ of the hydrolysate was adjusted to 7 using calcium hydroxide, the hydrolysate clarified (the salts precipitated) using the method described by Heding et al. (15). The supernatant was concentrated to $32 \mathrm{~B}^{\circ}$, FOS and inulin precipitated according to $\mathrm{Ku}$ et al. (20) method with some modifications. Acetone was used at ratios of $(4: 1 \mathrm{v} / \mathrm{v})$, then kept for three days in a refrigerator at $4^{\circ} \mathrm{C}$, centrifuged at $10000 \mathrm{~g}$ for $15 \mathrm{~min}$. The precipitate was washed with (60:40) (water: acetone) solution and centrifuged again at $10000 \mathrm{rpm}$ for 10 min., then mixed with $10 \mathrm{ml}$ distilled water, $1 \mathrm{~g}$ of maltodextrin and $0.01 \mathrm{~g}$ tri-calcium phosphate. The whole mixture placed in a drying oven at $110^{\circ} \mathrm{C}$ for $75 \mathrm{~min}$ to remove the remaining solvent then complete the drying at $55^{\circ} \mathrm{C}$ (35). The percentage of (FOS \& inulin) remaining after inulin hydrolysis was calculated according to Ngampanya et al. (26) method, using the following equation:

\section{Determination of total carbohydrate}

Phenolsulphuric acid method was used to estimate total carbohydrate (9) using DFructose for standard curve preparation.

\section{Determination of reducing sugar}

Dinitrosalicylic acid (DNSA) method was used to estimate reducing sugar using DFructose for standard curve preparation (23).

\section{Determination of free fructose}

Free Fructose was determined by resorcinol reagent method using D-Fructose as standard (4).

\section{Determination of moisture content}

The moisture content was determined using oven at $105^{\circ} \mathrm{C}, 2 \mathrm{~g}$ of sample placed in drying oven until gaining a constant weight (1).

\section{Determination of hydroxymethylfurfural (HMF)}

HMF content was determined using White (41) method. The yield of HMF was calculated using the following formula:

$\mathrm{HMF}(\mathrm{mg} / 100 \mathrm{~g})=\left(\mathrm{A}_{284}-\mathrm{A}_{336}\right) \times 21.39 \times \mathrm{W}$ $x \mathrm{D} / \mathrm{W}$ 
$\mathrm{A}_{284}=$ absorbance at $284 \mathrm{~nm}$

$\mathrm{A}_{336}=$ absorbance at $336 \mathrm{~nm}$

$21.39=$ Constant

$\mathrm{D}=$ dilution factor, in case dilution is necessary

$\mathrm{W}=$ Weight in $\mathrm{g}$ of the sample

\section{HPLC analysis}

Sample analysis was performed using RPHPLC Model LC-2010 a HT. UV-detector 190 nm. Equipped with a quaternary pump and Empower software. An NUCLEODUR $100-$ $5 \mathrm{NH} 2$ column (4.6 x $250 \mathrm{~mm}$ i.d.) was used at a column temperature of $40^{\circ} \mathrm{C}$. The mobile phase was mixture of acetonitrile/water $(75: 25)(\mathrm{v} / \mathrm{v})$ and flow rate of $1.4 \mathrm{ml} / \mathrm{min}$. The sample injection volume was $10 \mu \mathrm{l}$. Using (Fructose, Glucose, Sucrose, Cellobiose, raffinose, 1-Kestose and Inulin from Chicory root) as standards (31).

\section{Thin-layer chromatography identification}

The qualitative identification of inulin and FOS was performed by (TLC) before and after hydrolysis of inulin. Using (Fructose, Glucose, Sucrose, 1-Kestose and Inulin from Chicory root) as standards. Phase ascension is composed of a mixture of solvents: (butanolethanol-water) (5:3:2) (v: v: v). after drying the plate, the spots were visualised by spraying (aniline-diphenyl-amine-phosphoric acidacetone) (1:1:5:50) (v: w: v: v), followed by drying at $80{ }^{\circ} \mathrm{C}$ for $10 \mathrm{~min}$ until the spots appear clearly (29).

\section{Statistical analysis}

The data were statistically analyzed by the (LSD) value at 0.05 probability level as described in (13)

\section{RESULTS AND DISCUSSION}

\section{Chemical composition of JAT}

Table 1 shows the chemical composition of local JAT (fresh \& powder) which included (moisture, total solid, total carbohydrates, inulin, sucrose, reducing sugar and pectin). The total carbohydrate percentages were $(14.20 \%$ \& $61.74 \%)$ in fresh and dry JAT respectively. These amounts are consistent with Bekers et al. (6) findings who reported that the total carbohydrate content in different varieties of JAT powder was ranged $(62.8 \%$ $64.5 \%$ ). whereas in fresh JAT was $14.97 \%$ (5). The percentage of inulin in experimental JAT (fresh \& powder) were $(9.66 \%$ \& $42 \%)$ respectively. This is in line with Dias et al. (8) findings who reported that JAT powder contains a high percentage of inulin ranging from $(40 \%$ - 60\%). Sahar (34) stated that inulin content in fresh JAT was $9.60 \%$. The differences in inulin percentages are due to the varieties, degree of polymerization, harvest date, storage and the postharvest extraction methods. The high content of inulin makes JAT an important plant source for the production of inulin and FOS at the commercial level. The results in Table 1 also indicate that the moisture content of JAT (fresh \& powder) were $(77.0 \%$ \& $6.37 \%)$ respectively, these results are consistent with Munim et al. (24) finding who stated that the moisture content in fresh JAT was $78.01 \%$. Gaafar et al. (13) found that the moisture content in JAT powder was $6.36 \%$. The percentage of pectin in JAT (fresh \& powder) were $(3.29 \%$ \& $14.30 \%)$ respectively. Our results are in line with those of Toshkov et al. (39) who found that the pectin content in JAT powder was $14.80 \%$. In recent study the percentage of reducing sugar and sucrose in JAT powder were $(2.13 \% \& 3.31 \%)$ respectively. While in fresh JAT, those values were $(0.49 \%$ \& $2.13 \%)$ respectively. Our findings were lower than Barta \& Patkai (5) results who reported that JAT powder contained $(1.72 \%$ to $2.55 \%)$ reducing sugar and $(3.50 \%$ to $9.45 \%)$ sucrose.

Table 1. Chemical composition of JAT

\begin{tabular}{|l|c|c|}
\hline Constituents & $\begin{array}{c}\text { (\%) Fresh } \\
\text { JAT }\end{array}$ & $\begin{array}{c}\text { (\%) JAT } \\
\text { Powder }\end{array}$ \\
\hline Moisture & \multicolumn{2}{|c|}{} \\
Total solid & $\mathbf{7 7 . 0 0}$ & 6.37 \\
Total carbohydrates & $\mathbf{2 3 . 0 0}$ & 93.63 \\
Inulin & 9.66 & 61.74 \\
Pectin & 3.29 & 42.00 \\
Reducing sugars & 0.49 & 14.30 \\
Sucrose & 0.76 & 2.13 \\
& & 3.31 \\
\hline
\end{tabular}

The experiment runs in duplicate

Effect of microwave power and extraction time on extractable inulin (\%):

Figure 1 shows the effect of microwave power and extraction time on the inulin yield and extraction efficiency. The highest yield (39.61 and $36.38 \%$ ) of purified inulin observed with (700W $\backslash 5 \mathrm{~min} \& 450 \mathrm{~W} \backslash 14 \mathrm{~min})$ respectively, with no significant differences between them $(\mathrm{P}<0.05)$. However, there were significant differences in inulin yield between the $700 \mathrm{~W} \backslash$ 
5 min. treatments and the treatment with $350 \mathrm{~W} \backslash 14 \mathrm{~min}(33.87 \%)$. These results were close to the results of Ruo-ling (32) who found that the extraction efficiencyausing $700 \mathrm{~W}$ was better than $600 \mathrm{~W}$ and $500 \mathrm{~W}$, the highest yield of inulin was achieved with microwave power 700W 3 min. Concerning the extraction efficiency (EF), Fig. 1abindicated that the highest EF (94.34 \%) achieved with $700 \mathrm{w} / 5 \mathrm{~min}$., followed by $450 \mathrm{w} / 8 \mathrm{~min}(86.62$ $\%)$ and $350 \mathrm{w} / 14 \mathrm{~min}(80.64 \%)$. Gaafar et al. (13) reported that the highest EF of inulin was noticed at $80^{\circ} \mathrm{Cl} 90$ min using conventional heat reflux method. The high temperatures in closed vessels MAE resulted in improved extraction efficiency, since the motivation and solubility of analytes from the JAT powder will increases. While the surface tension and solvent viscosity will decrease as temperature increases, which will eventually improve solvent penetration, consequently the efficiency of the inulin extraction will increases, (11).

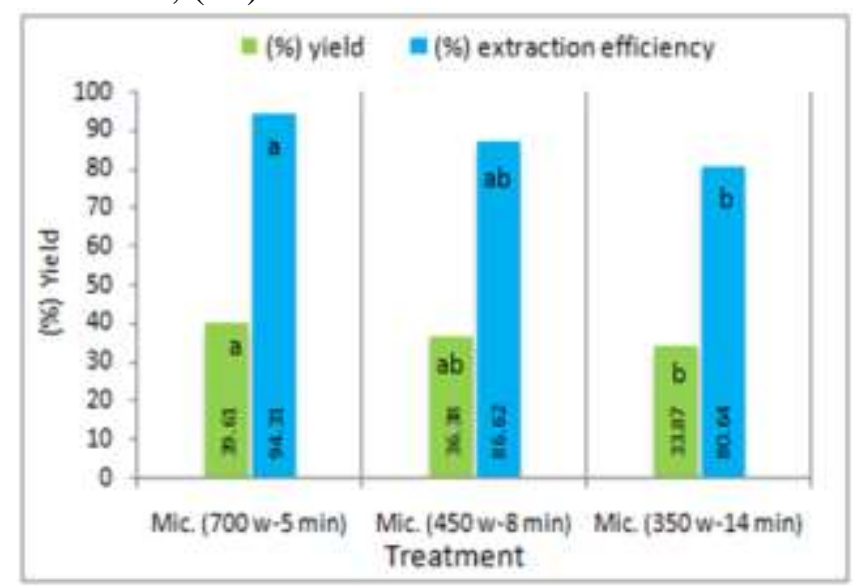

Figure 1. Effect of microwave power and extraction time on inulin yield and extraction efficiency (\%) from JAT powder Carbohydrate profiles and DPn of inulin obtained by RP-HPLC

The purified Inulin analyzed by RP-HPLC and compared with native chicory inulin, Fig. 2 shows that the fructose is a first monomer peak appeared, followed by glucose peak and disaccharide (sucrose), then the fructooligosacchrides peaks, which including (1-kestose GF2 and nystose GF3) etc. Results of current study shows that the DP of inulin ranging from $(2-35)$ unit. These results are consistent with Panchev et al. (27) who stated that the DP for inulin extracted from JAT ranging from $(2$ - 33) units. Based on the generally accepted presumption that the retention time of a inulin units increased as the degree of polymerization increased, and that each sequential peaks appeared in chromatographic pattern, represents an inulin moiety which had a fructose more than that of the previous peak. Additionally the well resolved peaks suggesting that inulin and FOS were linear units, as expected. However, it is not possible to distinguish between Fn or GFn. In most of the published studies, each sharp peak represents inulin units either of type of GFn or Fn, they appear after of sucrose peak (7). Furthermore Fig. 2 shows that the FOS DP ranging between $(2$ - 10) units, begging to appear after the sucrose unit. The FOS content in inulin extracted from JAT powder reaches $16 \%$, this refers to high content of JAT powder from FOS. Our results are in agreement with those of Judprasong et al. (16) who found that the content of FOS in inulin extracted from JAT was $19.18 \%$ as well as the percentage of reducing sugar reached to $3.22 \%$ (purified inulin). These results are consistent with Khuenpet et al. (18) who found that the reducing sugar content in JAT inulin was 3.45 $\%$. The percentage of remaining carbohydrates represents the pure inulin with DP more than 10 units.

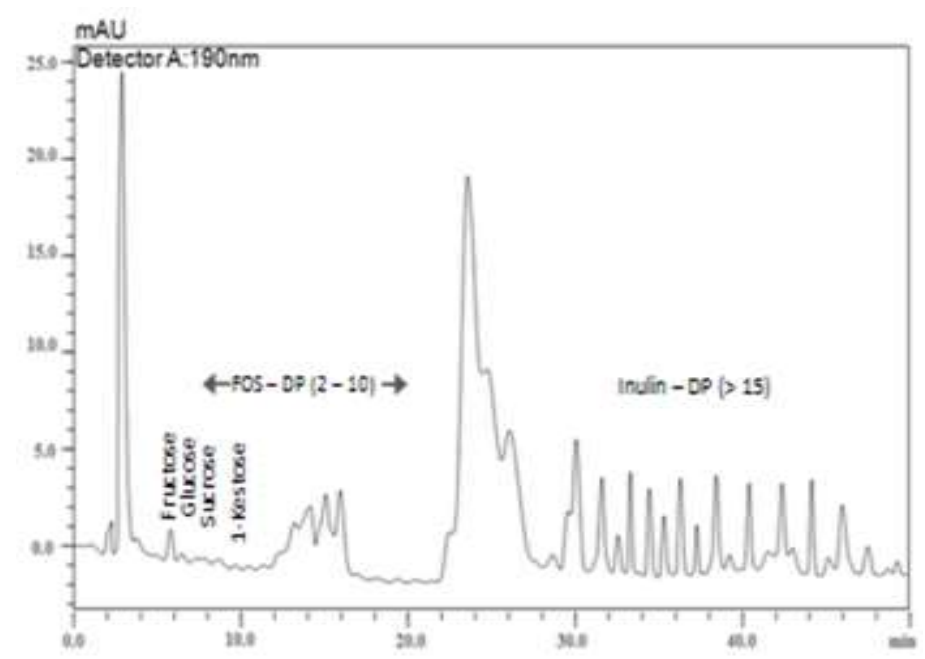

Figure 2. High-performance liquid chromate-graphic of inulin extracted from JAT. (FOS) fructo-oligosaccharides. (DP), degrees of polymerization

Qualitative analysis TLC of inulin extracted from JAT powder

TLC analysis of MAE inulin (Fig. 3), shows a polydisperse carbohydrate with different DP ranging from (3 - 9) units. The analysis of a TLC chromatogram of a homologous series of 
carbohydrates is based on the generally accepted assumption that each spots represents an inulin units with a certain DP value and that a higher DP leads to a decrease in the retention factor (RF). Therefore, it is assumed that each spot has one more fructose unit than the previous spot. Results of thin layer chromatography corresponded with RP-HPLC analysis in the inulin units separation, showed that the inulin extracted from JAT powder contains FOS appears as a separated spots on the glass silica gel. Then the spots overlap with each other gradually due to increasing of molecular weight, make it immobile with the mobile phase and remains close to the baseline. Our results are in line with those of Walz et al. (40) who found the first spots on TLC in line belongs to monosaccharides (fructose or glucose) with the lowest molecular weight, then sucrose and gradually other components of FOS or polysaccharide polymer chain with increasing molecular weight.

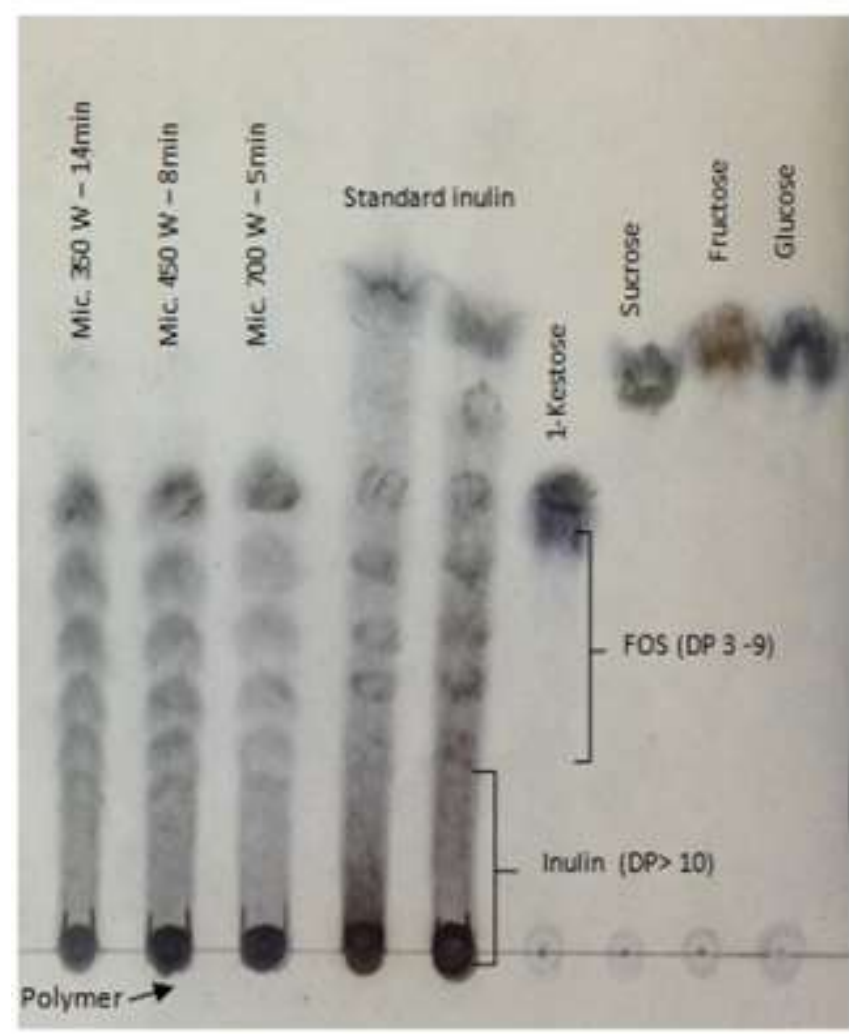

Figure 3. Thin layer chromatography of inulin extraction from JAT powder. (DP, degrees of polymerization; FOS, Fructooligosaccharides).
Optimization of inulin hydrolysis to produce FOS and high fructose syrup

Acid hydrolysis of inulin was carried out using different $\mathrm{pH}$ values and different hydrolysis period at $90^{\circ} \mathrm{C}$ (Fig. 4, $5 \&$ 6). Fig. 5 shows that the percentage of reducing sugars was increased with time from $(5-30) \mathrm{min}$. at $\mathrm{pH}$ 1.5. The percentage of (remaining inulin and produced FOS mixture) significantly $(\mathrm{p}<0.05)$ decreased from $(56.06 \%$ to $8.47 \%)$ during hydrolysis time (5 - 30) min. respectively. Fig. 4 also demonstrate that the percentage of reducing sugars was significantly $(p<0.05)$ increased from (43.94\% to $87.39 \%$ ) at the reaction time $(5$ - 30) min. respectively, Glibowski et al. (14) stated that using low $\mathrm{pH}$ values ranged from $(1-2) \backslash 90^{\circ} \mathrm{C}$ accelerated hydrolysis of the glycosidic bond, resulting in high percentage of free fructose.

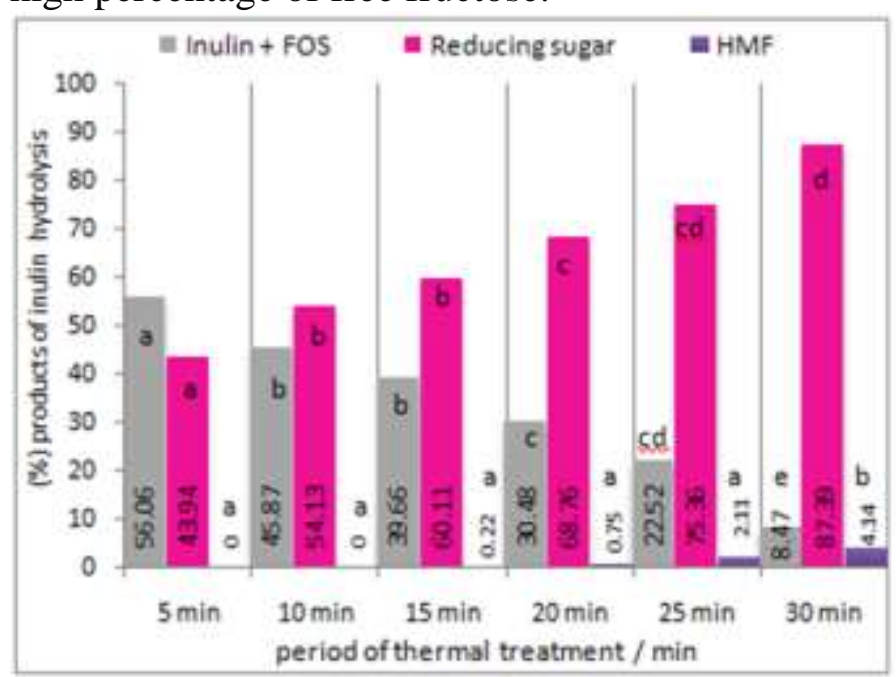

Figure 4. Percentages of (remaining inulin $\&$ produced FOS mixture), reducing sugar and HMF during acid hydrolysis of inulin $\left(\mathrm{pH} 1.5 \backslash 90^{\circ} \mathrm{C}\right.$ )

At $\mathrm{pH} 2.5$ the hydrolysis of inulin was lower than that at $\mathrm{pH}$ 1.5. Fig. 5 shows that the percentage of (remaining inulin and produced FOS mixture) were $(74.48,63.32,51.24$, $45.02,39.61,29.33) \%$ at $(5,10,15,20,25 \&$ 30) min. respectively. While, percentage of reducing sugars was increased as the reaction time increased at this $\mathrm{pH}$ value. The percentage of reducing sugars was $(25.52 \%)$ after 5 min. hydrolysis and it reached, $(68.36 \%)$ after $30 \mathrm{~min}$. of reaction time. Our results agreed with the study of Szambelan et al. (37) who stated that the low $\mathrm{pH}$ and high temperature enhanced the acid hydrolysis of inulin. 


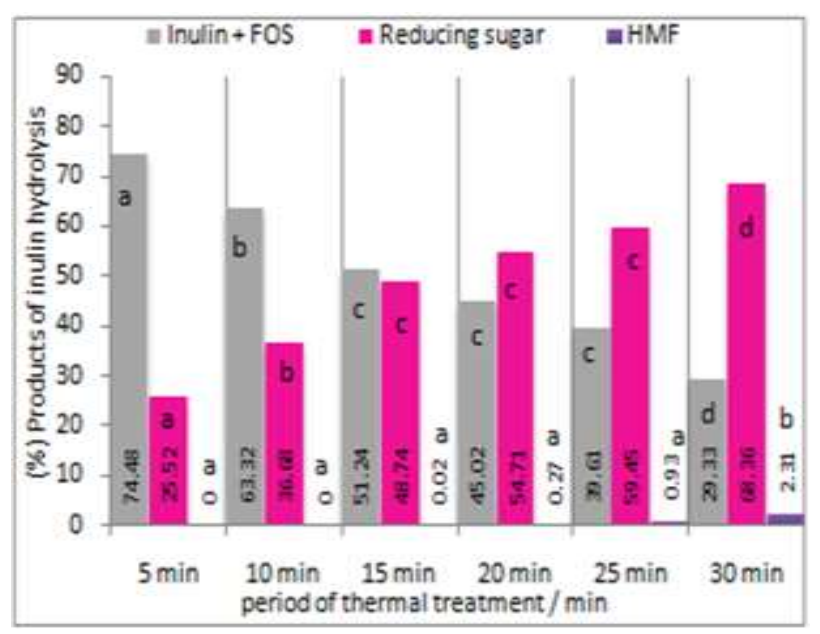

Figure 5. Percentages of (remaining inulin $\&$ produced FOS mixture), reducing sugar and $\mathrm{HMF}$ during acid hydrolysis of inulin $\left(\mathrm{pH} 2.5 \backslash 90^{\circ} \mathrm{C}\right)$

Fig. 6 shows the products of inulin hydrolysis at $\mathrm{pH} 3.00$ the depolymerization were slow, the percentage of (remaining inulin and produced FOS mixture) was $(80.87,75.50$, $64.74,57.82,48.57,37.01) \%$ at $(5,10,15,20$, $25 \& 30)$ min. hydrolysis respectively. The reducing sugars percentage were increased from $(19.13 \%$ to $37.01 \%)$ at $(5-30) \mathrm{min}$. hydrolysis respectively.

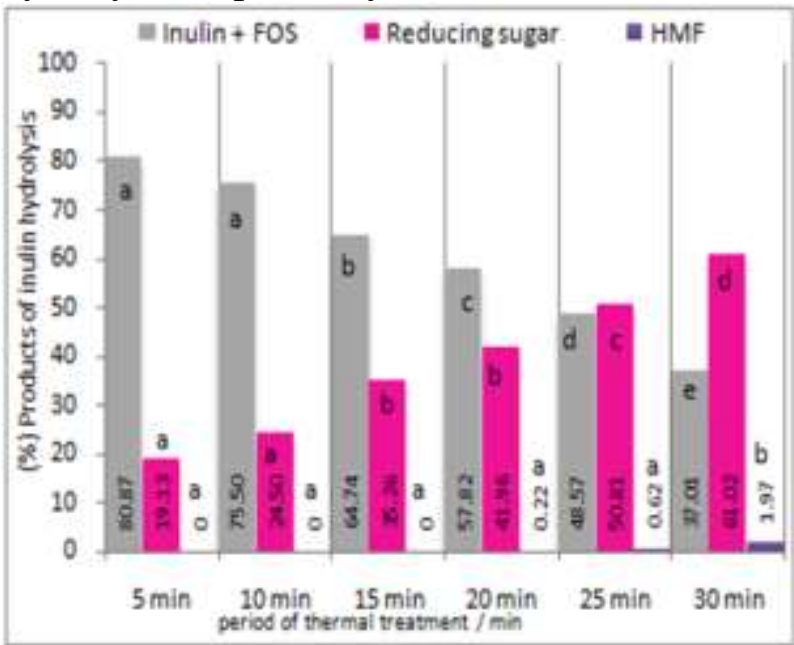

Figure 6. Percentages of (remaining inulin \& produced FOS mixture), reducing sugar and HMF during acid hydrolysis of inulin (pH 3.0 $\backslash 90^{\circ} \mathrm{C}$

The results of acidic hydrolysis of inulin at 90

${ }^{\circ} \mathrm{C}$ and $\mathrm{pH}$ values $(1.5,2.5$, and 3.0) shows that the amount of $\mathrm{HMF}$ increased as the reaction time increased. Fig. 5 shows that the highest percentage of $\mathrm{HMF}$ was $4.14 \%$ at $\mathrm{pH}$ 1.5 after 30 min. Fig. 6 also demonstrates that the HMF not formed during the initial stages of acid hydrolysis (pH 3) at $90^{\circ} \mathrm{C}$ up to $20 \mathrm{~min}$. of hydrolysis $(0.27 \%)$ then gradually increased to $(2.31 \%)$ after $30 \mathrm{~min}$. of reaction time. The amounts of HMF formed at $\mathrm{pH}(2.5 \& 3.0)$ were low as compared with $\mathrm{pH} 1.5$. Figure 7 demonstrates the same trend in HMF formation at the $\mathrm{pH}$ values. The co-generated HMF in small amount can be easily removed by adsorption with activated charcoal $(1 \%-$ $2 \%)(3,12)$. RP-HPLC and TLC indicated a wide range of modulation in the qualitative profile of the partial hydrolysis products for inulin. Optimal conditions of partial hydrolysis of inulin were studied to determine highest yield of FOS and lowest amount of free fructose. The optimum result for FOS production with less amounts of reducing sugars and $\mathrm{HMF}$, achieved at $\mathrm{pH} 2.5 \backslash 90{ }^{\circ} \mathrm{Cl}$ 15 min., as presented in (Fig.7). Under these conditions, the highest FOS (degree of polymerization, 2 to 9) yield was $39 \%$. Fontana et al. (12) stated that the best condition for acid hydrolysis of inulin were with citric acid catalyst $(\mathrm{pH} 2.5)$, temperature $85^{\circ} \mathrm{C}$ and reaction time $15 \mathrm{~min}$, which resulted in high amount of FOS with DP ranging from (2 - 9) units.

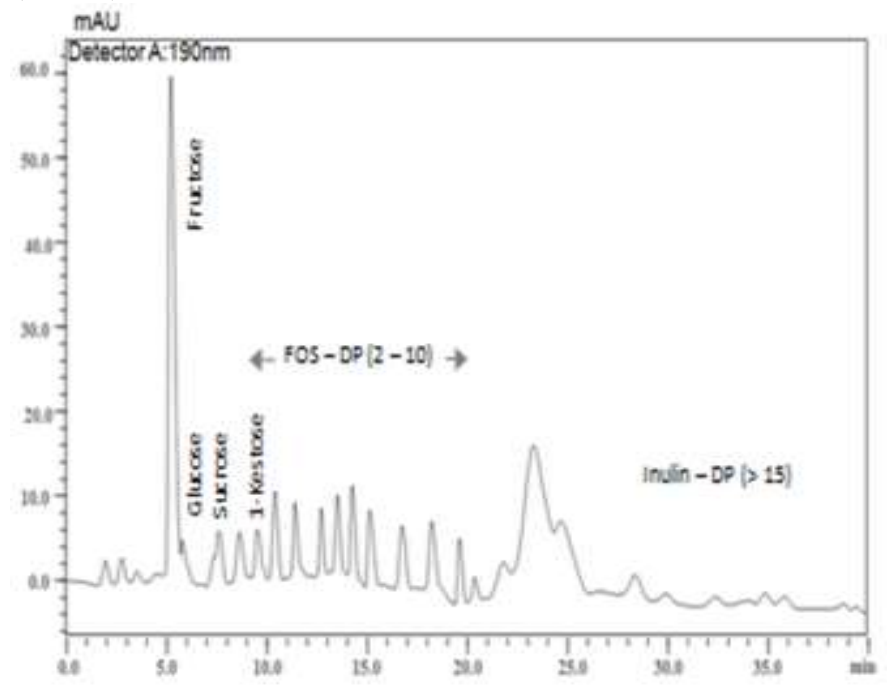

Figure 7. RP-HPLC profile of FOS obtained by inulin hydrolysis with citric acid at $\mathrm{pH}$ 2.5/15 min

Fig. 8 shows that the more acidic environment $(\mathrm{pH} 1.5)$ resulted in higher hydrolysis degree of inulin as the time proceeded from $(5-30)$ min. Consequently, the amount of free fructose increased, so these conditions can be applied for producing high fructose syrup. However, at $\mathrm{pH}$ (2.5) the hydrolysis of inulin was lower than that at $(\mathrm{pH} 1.5)$. The hydrolysis at $(\mathrm{pH}$ 2.5) recorded the highest percentage of FOS with low amount of free fructose through (5 - 
30) min. The Qualitative analysis indicates an increase in the amount of FOS through initial stages (hydrolysis time $15 \mathrm{~min}$ ) with continues increases of free fructose (up to $30 \mathrm{~min}$ ). Whereas hydrolysis of inulin at $\mathrm{pH} 3.0$ was less effective in depolymerization of inulin. Thus, for better hydrolysis of inulin at this $\mathrm{pH}$ required higher temperature and longer hydrolysis times.

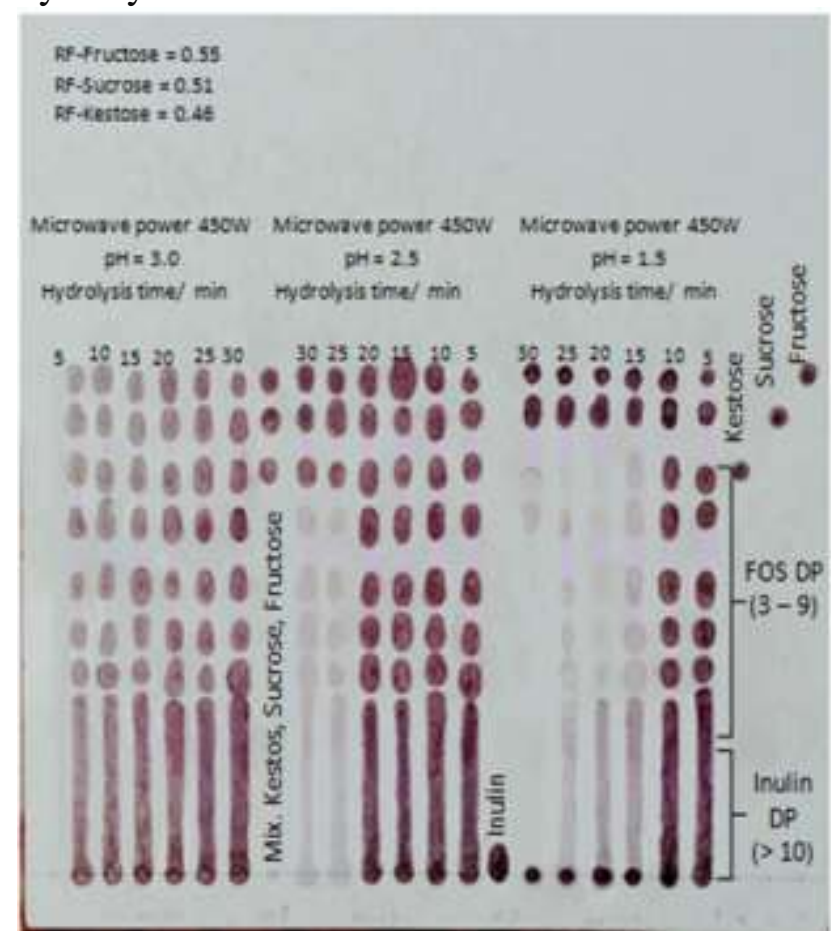

Figure 8. Thin-layer chromatographic analysis of the reaction products in the hydrolysis of inulin extracted from JAT with citric acid at $\mathrm{pH}(1.5,2.5 \& 3.0)$ for $(5$, $10,15,20,25,30) \mathrm{min}$. DP, degrees of polymerization; FOS, fructooligosaccharides

Purified inulin was prepared from JAT powder through Microwave-assisted extraction has been considered as a potential alternative to traditional solid-liquid extraction for the increasing of inulin yield from JAT powder. Optimum conditions for extracted inulin were using microwave power $700 \mathrm{~W} \backslash 95{ }^{\circ} \mathrm{C}$ for 5 min. Under these conditions high amount of inulin could be extracted $(39.61 \%)$ with better extraction efficiency $(94.31 \%)$. This inulin polymer was efficiently and partially depolymerized with aqueous citric acid to release FOS, with a degree of polymerization ranging from $(2-9)$, at $\mathrm{pH} 2.5$, the temperature was $85-90{ }^{\circ} \mathrm{C}$, and the hydrolysis time was $5-30 \mathrm{~min}$. There is no need for catalyst removal in most industrial applications of the FOS syrups that are produced with citric acid.

\section{REFERENCES}

1. AOAC, 2010. Official Methods of Analysis of Association of Official Analytical Chemists. $18^{\text {th }}$ Ed., Washington, D.C., USA

2. Al-juthery, H. W. A., and S. F. Saadoun. 2018. Impact of foliar application of some micrnutrients nanaofertilizer on growth and yield of jerusalem artichoke. The Iraqi Journal of Agricultural Science, 49(4): 577

3. Al-Rubaia'ay, H. F., and K. A. Shakir. 2018. Production of xylose using acid hydrolysis of wheat straw. The Iraqi Journal of Agricultural Science, 49(2): 219-227

4. Ashwell, G. 1957. In Methods in Enzymology (Colowick, S. P. and Kaplan, N. O., eds.). 3, 73-105 Academic Press, New York

5. Barta, J., and G. Y. Patkai. 2007. Chemical composition and storability of Jerusalem artichoke tubers. Acta Alimentaria, 36(2): 257267

6. Bekers, M.; M. Grube; D. Upite; E. Kaminska; A. Danilevich, and U. Viesturs. 2008. Inulin Syrup from Dried Jerusalem artichoke. LLU Raksti 21 (315): 116-121

7. Corradini, C.; F. Bianchi; D. Matteuzzi; A. Amoretti; M. Rossi and, S. Zanoni. 2004. High-performance anion-exchange chromategraphy coupled with pulsed amperometric detection and capillary zone electrophoresis with indirect ultra violet detection as powerful tools to evaluate prebiotic properties of fructooligo-saccharides and inulin. Journal of Chromatography a, 1054(1-2): 165-173

8. Dias, N. S.; J. F. S. Ferreira; X. Liu, and D. L. Suarez. 2016. Jerusalem artichoke (Helianthus tuberosus, L.) maintains high inulin, tuber yield, and antioxidant capacity under moderately-saline irrigation waters. Industrial Crops and Products 94, 1009-1024 9. Dubois, M.; K. A. Gilles, J. K. Hamilton; P. A. Rebers, and F. Smith. 1956. Anal Chem, (26): 340- 350

10. El-Kholy, W. M. and H. Mahrous. 2015. Biological studies on bio-yoghurt fortified with prebiotic obtained from jerusalem artichoke. Food and Nutrition Sciences, 6(16): 1548- 1552 
11. Eskilsson, C. S. and E. Bjorklund. 2000. Analytical-scale

extraction. Journal of chromatography A, 902(1): 227-250

12. Fontana, J. D.; A. Grzybowski; M. Tiboni, and M. Passos. 2011. Fructooligosaccharide production from inulin through partial citric or phosphoric acid hydrolyses. Journal of medicinal food, 14(11): 1425-1430

13. Gaafar, A.; E. Boudy, and H. El-Gazar. 2010. Extraction conditions of inulin from Jerusalem artichoke tubers and its effects on blood glucose and lipid profile in diabetic rats. Journal of American Science, 6(5): 36-43

14. Glibowski, P., and A. Bukowska. 2011. The effect of $\mathrm{pH}$, temperature and heating time on inulin chemical stability. Acta Scientiarum Polonorum Technologia Alimentaria, 10(2): 189-196

15. Heding, L. G. and J. K. Gupta. 1975. Improvement of conditions for precipitation of citric acid from fermentation mash. Biotechnology and Bioengineering, 17(9), 1363-1364 16. Judprasong, K.; S. Tanjor; P. Puwastien, and P. Sungpuag. 2011. Investigation of Thai plants for potential sources of inulin-type fructans. J. Food Compos. Anal. 24, 642-649

17. Khaleel, M. M., and A. A. Thaer. 2017. Using probiotics and inulin to prolong ferminted dairy products shelef life. Iraqi Journal of Agricultural Sciences, 48(2): 608617

18. Khuenpet, K.; M. Fukuoka; W. Jittanit, and S. Sirisansaneeyakul. 2017. Spray drying of inulin component extracted from Jerusalem artichoke tuber powder using conventional and ohmic-ultrasonic heating for extraction process. Journal of Food Engineering. 194, 6778

19. Koubaa, M.; E. Rosello-Soto; J. Sic Zlabur; A. Rezek Jambrak; M. Brncic; N. Grimi, and F. J. Barba. 2015. Current and new insights in the sustainable and green recovery of nutritionally valuable compounds from Stevia rebaudiana Bertoni. Journal of Agricultural and Food Chemistry, 63, 68356846

20. Ku, Y.; O. Jansen; C. J. Oles; E. Z. Lazar and J. I. Rader. 2003. Precipitation of inulins and oligoglucoses by ethanol and other solvents. Food chemistry, 81(1): 125-132
21. Liu, S.; X. Shi; L. Xu, and Y. Yi. 2016. Optimization of pectin extraction and antioxidant activities from Jerusalem artichoke. Chinese journal of oceanology and limnology, 34(2): 372-381

22. Mensink, M. A.; H. W. Frijlink; K. V. Maarschalk and W. L. J. Hinrichs. 2015. Inulin, a flexible oligosaccharide I: Review of its physic-chemical characteristics, Carbohydrate Polymers

23. Miller, G. L. 1959. Use of dinitrosalicylic acid reagent for determination of reducing sugar. Analytical Chemistry, 31, 420-428

24. Munim, A.; M. Rod; H. Tavakoli, and F. Hosseinian. 2017. An analysis of the composition, health benefits, and future market potential of the jerusalem artichoke in canada. Journal of Food Research. 6(5): 69-84 25. Mutanda, T.; B. S. Wilhelmi, and C. G. Whiteley. 2015. Biocatalytic conversion of inulin and sucrose into short chain oligosaccharides for potential pharmaceutical applications. African Journal of Science, Technology, Innovation and Development, 7(5): 371-380

26. Ngampanya, B.; S. Keayarsa; P. Jaturapiree; P. Prakobpran and S. Wichienchot. 2016. Characterization of transfructosylating activity enzyme from tubers of tropical Jerusalem artichoke (Helianthus tuberosus L.) for production of fructooligosaccharides. International Food Research Journal, 23(5): 1965-1972

27. Panchev, I.; N. Delchev; D. Kovacheva and A. Slavov. 2011. Physicochemical characteristics of inulins obtained from Jerusalem artichoke (Helianthus tuberosus L.). European Food Research and Technology, 233, 889-896

28. Paseephol, T.; D. Small, and F. Sherkat. 2007. Process optimisation for fractionating Jerusalem artichoke fructans with ethanol using response surface methodology. Food Chemistry, 104 (1): 73-80

29. Reiffova, K. and R. Nemcova. 2006. Thinlayer chromatography analysis of fructooligosaccharides in biological samples. Journal of Chromatography A, 1110(1-2): 214-221

30. Roberfroid, M. B. (2008). Prebiotics: Concept, Definition, Criteria, Methodologies, and Products. In Handbook of prebiotics, pp: 49-78 
31. Rodriguez-Gomez, R.; I. Jimenez-Diaz; A. Zafra-Gomez and J. C. Morales. 2015. Improved sample treatment for the determination of fructooligosaccharides in milk related products by liquid chromatography with electrochemical and refractive index detection. Talanta, 144, 883889

32. Ruo-ling, J. I. A. 2012. Microwave extraction of inulin from jerusalem artichoke. Journal of Anhui Agricultural Sciences, 23, 15-21

33. Saengkanuk, A.; S. Nuchadomrong; S. Jogloy; A. Patanothai and S. Srijaranai. 2011. A simplified spectrophotometric method for the determination of inulin in Jerusalem artichoke (Helianthus tuberosus L.) tubers. European Food Research and Technology, 233(4): 609-616

34. Sahar, R. A. 2003. Utilization of Jerusalem Artichoke Tubes and Their Extracted Inulin in Preparing Some Foods for Diabetic Patients (Doctoral dissertation, $\mathrm{PhD}$ Thesis, Food Science and Technology Department, Faculty of Agriculture, Kafr El-Sheikh, Tanta University, Tanta).

35. Sangeetha, P. T. 2003. Microbial Production Of Fructooligosaccharides (Doctoral dissertation, University of Mysore) pp: 237-247

36. Srinameb, B. O.; S. Nuchadomrong; S. Jogloy; A. Patanothai and S. Srijaranai. 2015. Preparation of inulin powder from Jerusalem artichoke (Helianthus tuberosus L.) tuber. Plant foods for human nutrition, 70(2): 221-226

37. Szambelan, K. and J. Nowak. 2006. Acid and enzymatic hydrolysis of Jerusalem artichoke (Helianthus tuberosus L.) tubers for further ethanol production. Electronic Journal of Polish Agricultural Universities. Series Food Science and Technology, 9(4): 690-697 38. Temkov, M.; N. Petkova; P. Denev and A. Krastanov. 2015. Characterization of inulin from Helianthus tuberosus L. obtained by different extraction methods-Comparative study. Proceeding of Scientific Works of University of Food Technologies. 5, 461-464

39. Toshkov, N.; N. Delchev, and S. Kozludzhova. 2014. Sorption characteristics of pectin isolated from Jerusalem Artichoke tubers (Helianthus tuberosus L.). Ukrainian Food Journal, 3 (2): 185-192

40. Walz, M.; D. Hagemann; M. Trentzsch; A. Weber and T. Henle. 2018. Degradation studies of modified inulin as potential encapsulation material for colon targeting and release of mesalamine. Carbohydrate polymers, 199, 102-108

41. White, J. W. 1979. Spectrophotometric method for hydroxymethylfurfural in honey. $\mathrm{J}$ Assoc Off Anal Chem, 62, 509-514

42. Xie, J. H.; M. Y. Xie; M. Y. Shen; S. P. Nie; C. Li and Y. X. Wang. 2010. Optimization of microwave-assisted extraction of polysaccharides from Cyclocarya paliurus (Batal.) Iljins-kaja using response surface methodology. Journal of the Science of Food and Agriculture, 90(8): 1353-1360

43. Zhou, H. 2008. Rapid determination of solanesol in tobacco by high performance liquid chromatography with evaporative light scattering detection following microwaveassisted extraction. Journal of Chromatography B, 835: 119-122 